УДК 628.74 .05

(C) 2014

\author{
Прасолов С. Я., кандидат технічних наук, \\ Кулик О. В., викладач, \\ Свинтитська К. В., викладач \\ Полтавська державна аграрна академія
}

\title{
ПРИЧИНИ САМОЗАЙМАННЯ ТЕХНІКИ ТА ЗАСТОСУВАННЯ ЕКОЛОГІЧНИХ СОРБЕНТІВ ДЛЯ ПРИПИНЕННЯ ВОГНЮ
}

\section{Рецензент - кандидат технічних наук В. М. Сакало}

У статті приведені дослідження причини самозаймання сільськогосподарської техніки, зокрема, зернозбиральних комбайнів. Проведено аналіз відомих засобів гасіння пожеж. Виконані дослідження зі встановлення ефективного екологічно безпечного та економічно дочільного засобу пожежогасіння. Досліди проводилися з визначенням вогнегасної здатності щуодо гасіння модельних вогнищ класів A $i$ B. Запропоновано склад сумішей на основі бішофіту для гасіння. У такому разі знижується собівартість прочесу гасіння пожеж, досягається екологічна безпека довкілля, ліквідується шкідлива дія засобу пожежогасіння на вогнебориів.

Ключові слова: тепло механічної енертї̈, хімічні прочеси; електрична енертія, відкритий вогонь; бішофіт, глауконіт, вогнегасна здатність.

Постановка питання. Виникнення неконтрольованого осередку вогню та його розповсюдження $є$ фактором ризику, що загрожує здоров'ю людей, довкіллю, матеріальному стану громадян, підприємств і державі в цілому. В сучасному пожежогасінні актуальним завданням $є$ гарантоване припинення вогню. До того ж, необхідно забезпечити зниження енергоємності та собівартості процесу й екологічну безпеку навколишнього середовища. Великомасштабні механізовані роботи виконуються в АПК у ході збирання зернових культур у стислі агротехнічні терміни. Важливою умовою проведення таких робіт є дотримання виробничої безпеки, в тому числі захист урожаю й сільськогосподарської техніки від займання вогнем. Нині у вогнеборців виникла проблема, а саме недостатнє забезпечення ефективними, недорогими й екологічно безпечними засобами пожежогасіння, передусім під час машинного збирання зернових культур [5-8].

Аналіз останніх досліджень і публікацій, у яких започатковано розв'язання проблеми. У відомих засобах гасіння пожеж використовується повітряно-механічна піна низької й середньої кратності та синтетичні вогнегасні порошки. У композиціях піноутворювачів для гасіння пожеж - синтетичні аніоно-активні, поверхнево- активні речовини-порошки певних фракцій та їх суміші, модифіковані добавки [1-4].

Однак, у рецептурах таких піноутворювачів через застосування синтетичних поверхневоактивних речовин та їх сумішей, а також введення модифікованих добавок для досягнення необхідних експлуатаційних показників підвищується, по-перше, вартість вогнегасної речовини, а, по-друге, підвищується шкідлива дія на людей та довкілля. Крім того, такі протипожежні засоби мають недостатню продуктивність, є екологічно небезпечними й економічно недоцільними, а також обмежені сировинною базою.

На відміну від промислових засобів, порошкові композиції для гасіння пожеж діють наступним чином: заповнюють палюче середовище порошковою хмарою або продуктами розпаду порошку, після чого зона загоряння охолоджується за рахунок втрати тепла на нагрів порошку й, частково, на випаровування та розкидання частинок у полум'ї. Проте такі порошкові протипожежні засоби не забезпечують необхідної подачі до осередку горіння, стабільного процесу пожежогасіння, мають низьку тривалість захисної дії, що зменшує надійність їх застосування. Крім того їх використання обмежене, порівняно високою вартістю вихідної сировини.

Мета досліджень: провести аналіз і визначити причини самозаймання сільськогосподарської техніки та розробити високопродуктивний екологічно безпечний й економічно доцільний засіб пожежогасіння.

Завдання: визначити оптимальний вміст його складових із забезпеченням стабільності результатів і високої ефективності в різних пожежних умовах з урахуванням вимог екологічної безпеки й умов праці вогнеборців.

Результати досліджень. Зернозбиральні комбайни працюють у полі в умовах високих температур повітря, наявності значної кількості легкозаймистих рослинних решток. Зрозуміло, що за сталої сухої погоди і після вегетаційного періоду, коли рослини починають засихати, їх стебла 
перетворюються в висохлу масу соломи, в силу чого зростає пожежна небезпека $[7,8]$.

У зернозбирального комбайна пожежонебезпечними вузлами є: двигун, соломотряс, молотильно-сепаруючий пристрій, паливний бак, масло- та паливопроводи. Дослідженнями встановлені показники займання та причини пожежі на зернозбиральних комбайнах [7].

Такі ситуації виникали в результаті: а) короткого замикання електричної проводки, що становило приблизно 45 \%; б) самозаймання намотаної солом'яної маси на вали приймального та відбійного літерів, граблини мотовила, підбурника соломи, а також полови набивача на ексцентрик приводу різального апарату, на вал клавіш соломотряса, що становило приблизно $20 \%$; в) тепловиділення за рахунок тертя деталей соломотряса, що становило приблизно $10 \%$, решта - близько $25 \%$.

У процесі дослідження властивостей горючої маси під час збиральних робіт піддавались аналізу такі речовини: а) залишкова солома на полях $\mathrm{i}$ на техніці теплота горіння $\mathrm{Q}=177084$ кДж/кг; б) температура займання $\mathrm{T}_{3}=200{ }^{\circ} \mathrm{C}$; температура самозаймання $\mathrm{T}_{\text {сз }}=310{ }^{\circ} \mathrm{C}$; температура самонагрівання $80^{\circ} \mathrm{C}$; в) зерновий пил, що знаходився на збиральній техніці, та зерно на токах; г) витік палива з баків технічних засобів; д) фарбове покриття деталей техніки. Джерелами займання горючої суміші під час збирання урожаю зернових культур можуть бути: тепло механічної енергії, тепло хімічних процесів, тепло електричної енергіï та відкритий вогонь. Тепло механічної енергії виникає за збирання урожаю самохідною зернозбиральною технікою, що має чималу кількість обертових і тертьових деталей. Деталі машин і рослинна маса нагріваються тертям вище допустимих температур - це призводить до займання маси соломи, що знаходиться на валах і робочих органах [6-8].

Тепло електричної енергії виникає в сучасної самохідної зернозбиральної техніки, що має високу ступінь насиченості електроустаткуванням. У мережі напруга невисока (12-24 В), але численні високі значення струмових навантажень (5-500 А) достатні для виникнення іскриння в разі неякісних контактів або короткого замикання. Пожежонебезпечними можуть бути пересувні генератори для освітлення і підзарядки акумуляторів. Не слід виключати й можливість виникнення самозаймання внаслідок розрядів атмосферної електрики під час грози.

Мастильні речовини, що використовуються для змащування вузлів і механізмів техніки, теж є горючими речовинами.
Відкритий вогонь та іскриння виникають у разі необережного користування вогнем та за відсутності або несправності іскрогарячих пристроїв самохідної зернозбиральної техніки. Зауважимо, що сільськогосподарська техніка забезпечується іскрогасними пристроями на заводах, однак вони швидко виходять із ладу [7, 8].

Для забезпечення пожежної безпеки слід:

a) тримати техніку, наприклад комбайни, в чистоті;

б) періодично перевіряти кріплення барабана та відбійного бітера на валах та зазор між обертовими деталями комбайна і каркасом;

в) не перегрівати підшипники, тобто своєчасно змащувати їх;

г) перевіряти надійність кріплення зазамелення на балці, мости ведучих коліс;

д) заправляти паливні баки за площею хлібних масивів;

е) зберігати паливно-мастильні речовини для комбайна в закритій тарі;

ж) під час сильного вітру тимчасово призупиняти техніку.

Шляхом спостережень встановлено, що за високого та густого масиву пшениці у випадку сильного вітру та засушливії погоди швидкість розповсюдження пожежі досягає 10 м/c, а за рідкої та низькорослої рослинності й відсутності вітру швидкість розповсюдження пожежі сягає $0,3 \mathrm{M} / \mathrm{c}$.

Нерідко під час пожежі завдяки різниці температур потоків повітря виникає «смерч», який може перекинутися на значні віддалі через створені штучні й природні перепони (полоси, дороги, річки) [8].

У разі виникнення пожежі під час збирання врожаю у комбайна звільняють соломонакопичувач, гасять вогонь на двигуні, використовуючи воду, пісок, землю, вогнегасники. Слід прийняти заходи 3 попередження розповсюдження вогню на хлібний масив або валки. Для цього попереду фронту вогню роблять покоси в декілька прогонів, після чого виорюють полоси. На сільськогосподарській техніці пожежа розповсюджується через пил. Якщо пожежа виникає в приміщенні сушарок, то, в першу чергу, слід евакуювати 3 небезпечної зони працівників і використати засоби пожежогасіння.

Нині розроблено чимало способів і засобів пожежогасіння, але використання порошкових композицій вивчені недостатньо (за гасіння пожеж у ході збирання зернових культур технікою).

Розглянемо розробку ефективного екологічно безпечного та економічно доцільного засобу по- 
жежогасіння.

Для отримання максимальної ефективності пожежогасіння пропонується застосовувати екологічний сорбент - бішофіт - як засіб пожежогасіння і припинення вогню. Для створення протипожежного засобу розроблено композицію, що включає екологічно чисті компоненти: бішофіт $\mathrm{i}$ глауконіт у вигляді порошку із наночастинок та тверді негорючі частинки розміром 0,09-0,65 мм, наприклад, із оксиду заліза, які рівномірно розподілені в суміші. До того ж визначено пропорції вмісту компонентів у наступному співвідношенні (мас., \%): бішофіт - 73,0-27,0; глауконіт 23,5-58,0; тверді негорючі частинки (наприклад, оксид заліза) - 3,5-15,0 [5, 6].

Бішофіт - природний мінерал, що представляє собою комплексний екологічний сорбент. Хлоридно-магнієвий мінерал - бішофіт - містить близько 80-90 \% сполук магнію, мікроелементи, бром, цинк, марганець, магній, калій, кальцій, натрій, йод, залізо, літій, титан, свинець.

Його поклади знаходяться у ДністровськоДонецькій западині з товщиною шару до двох метрів. Полтавський бішофіт відрізняється підвищеним вмістом брому та чистотою. Бішофіт має високу розчинність у воді, за сумарною активністю природних радіонуклідів відноситься до першого класу й може використовуватися без обмежень.

Друга складова композиції для пожежогасіння - глауконіт. Це комплексний екологічно чистий сорбент. Буває природний і модифікований, зеленого кольору 3 різними відтінками, об'єднує слюдисті мінерали пошарової структури й містить оксидні форми заліза, магнію, калію.

Були проведені дослідження: а) зі встановлення доцільності використання бішофіту в якості засобу пожежогасіння і припинення вогню; б) зі встановлення оптимальних пропорцій вмісту складових композицій для пожежогасіння на основі бішофіту.

Проводилися візуальні дослідження 3 гасіння модельних вогнищ пожеж нафтопродуктів. Враховуючи властивості бішофіту, встановлено, що припинення горіння досягається руйнуванням продуктів з їх одночасною сорбцією. Під час подачі його під тиском на поверхню модельної пожежі, порошок покриває поверхню й за рахунок нерозчинності, хімічної стабільності та відсутності летючих компонентів повністю припиняє реакцію горіння, виключаючи можливість іiі відновлення $[5,6]$.

Витрати на гасіння пожеж залежать від вартості вогнегасник речовин. У даному випадку собівартість запропонованого бішофіту для пожежо- гасіння значно нижча, ніж собівартість синтетичної речовини.

Аналіз результатів досліджень показує, що збільшується площа, яка покривається факелом розпилу, зменшується кількість необхідного вогнегасного бішофіт-порошку для гасіння осередку полум'я, збільшується тривалість захисної дії вогнегасного порошку, підвищується надійність способу гасіння полум'я. Таким чином, екологічний сорбент - бішофіт - підтвердив свою ефективність як засіб пожежогасіння.

На наступному етапі проводилися дослідження зі встановлення ефективності композиції на основі бішофіту. Виходячи 3 характеристик складових композиції для пожежогасіння, видно, що до складу входять природні неорганічні мінерали та речовини, які забезпечують високу надійність гасіння, екологічну безпеку, мінімальні витрати на гасіння.

Для випробування композиції (аналогічно до першої серії дослідів) iї завантажували в рухомий порошковий вогнегасник, з якого порошкова композиція протягом 80 секунд витискається стиснутим до 15,0 МПа повітрям (азотом) у зону (осередок) горіння 3 покриттям площі близько 3 м². Композиція для пожежогасіння 3 7,5\% часток розміром 0,09-0,65 мм випробувана для гасіння пожежі класу В із забезпеченням вогнегасної

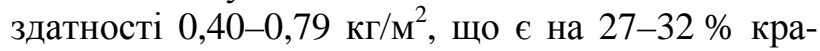
щою порівняно 3 аналогічними протипожежними засобами. Не виключається й інша схема підготовки композиції.

Визначення вогнегасної здатності щодо гасіння модельних вогнищ класу А і В проводилися згідно 3 ДСТУ 3675-98 п. 7.5 та ДСТУ 3734-98, п. 4.14.

Результати досліджень показників властивостей бішофіту та композиції на його основі відповідають вимогам нормативних документів.

Висновок. За результатами досліджень встановлені: показники самозаймання та причини пожеж на зернозбиральних комбайнах, проведений аналіз механізму виникнення джерел запалювання горючого середовища під час проведення зернозбиральних робіт, що дасть змогу систематизувати експлуатаційні вимоги до зернозбиральної техніки, чим можна гарантувати виробничу безпеку. Бішофіт та композиція на його основі відносяться до засобів пожежогасіння й можуть використовуватися вогнеборцями для гасіння пожеж на зернозбиральних комбайнах під час сільськогосподарських робіт. У такому разі знижується собівартість процесу гасіння пожеж, досягається екологічна безпека навколишнього середовища й ліквідується шкідлива дія засобу пожежогасіння на вогнеборців. 


\section{БІБЛІОГРАФІЯ}

1. Антонов А. В. Теоретические и практические вопросы разработки огнетушащих веществ в Украине / А. В. Антонов. - М : ВНИИПО МВД России, 2001. - С. 10-12. (Материалы XVI научно-практической конференции. - Ч. 2).

2. Демидов П. Г. Горение и свойства горючих материалов / П. Г. Демидов. - М. : ВИПТШ МВД, 1981. - $190 \mathrm{c}$.

3. Иванников В. П. Справочник по тушению пожаров / В. П. Иванников. - К. : МВД Украины, 1995. $-250 \mathrm{c}$.

4. Кащеев Н. Б. Пожарные машины и противопожарное оборудование - М. : Стройиздат, 1966. - $311 \mathrm{c}$.

5. Патент України №59925 від 10.06.2011p., бюл. №11. Застосування бішофіту для пожежогасіння і припинення вогню / Писаренко П. В., Писаренко В. М., Педора Є. В., Браженко С. А., Прасолов С.Я., Писаренко В. В., Куниць- кий В. М., Твердохліб О. В., Квилінський Я. В., Остиста О. Г., Шовкова О. В.

6. Патент України №59941 від 10.06.2011 р., бюл. №11. Композиція для пожежогасіння / Писаренко П. В., Писаренко В. М., Писаренко В. В., Браженко С. А., Прасолов С. Я., Педора Є. В., Куницький В. М., Кривошеєв В. В., Квилінський Я. В., Остиста О. Г., Шовкова О. В.

7. Рекомендации по безопасности труда при выполнении различных сельскохозяйственных работ, монтаже и эксплуатации оборудования животноводческих и птицеводческих ферм и техническом сервисе. - М. : Информагротех, 1999. - $216 \mathrm{c}$.

8. Шкрабак В. С. Безопасность жизнедеятельности в сельскохозяйственном производстве / В. С. Шкрабак, А. В. Луковников, А. К. Тургиев. - М. : Колос, 2004. - 512 с. 